DOI https://doi.org/10.32841/2409-1154.2021.51-1.11

\author{
Ivasiuk O. V., \\ Candidate of Philological Sciences, \\ Lecturer at the department of the English language of technical orientation № 1 \\ National Technical University of Ukraine of "Igor Sikorsky Kyiv Polytechnic Institute"
}

Doronkina N. Ye.,

Senior Lecturer at the department of the English language of technical orientation № 1 National Technical University of Ukraine of "Igor Sikorsky Kyiv Polytechnic Institute"

\title{
ARGUMENTATION FEATURES OF SCIENTIFIC REVIEW PAPER IN THE CONTEXT OF RHETORICAL STRUCTURE THEORY
}

\begin{abstract}
Summary. The research focuses on the attempt to apply rhetorical structure theory to the argumentative structure description of scientific review article. The purpose of the investigation is both to highlight the features that are peculiar to scientific review paper as a subgenre of scientific article and to outline semantic relations between the components of its argumentative structure. The methods of study are: genre analysis, intention analysis, function analysis and analysis of rhetorical structures. Such characteristics of scientific article as composition, communicative and scientific tasks and some constitutive requirements are considered. The following criteria to select a certain type of article for scientific review are discussed: the way of text presentation, communicative and scientific tasks, type of research, sphere of scientific activity and scientific substyle. The study of scientific review paper was made in terms of the approach suggesting the presence of argumentative fragments in the text investigated. The structure of each fragment is based on the model proposed by $\mathrm{S}$. Toulmin. Since argumentative structure of scientific article is presented in the form of hierarchical formation the features of scientific review peculiar to each of levels are analyzed. It was found that argumentative structure of scientific review paper consists of two parts. The first is localized in the chapter of introduction. It is devoted to the problem formulation and persuasion the reader of article in desirability to revise a number of ways to solve it. The second part of argumentative structure belongs to coordinate type of complex argumentation for the benefit of the article conclusions. Rhetorical relations typical for scientific review arguments were mentioned. The study is illustrated with text fragments of two scientific reviews in the sphere of science and technology.
\end{abstract}

Key words: coordinate argumentation, rhetorical relation, subgenre, discourse, hierarchical formation, abstract, justification.

Problem statement. Rhetorical structure theory (RST) developed in the eighties of the $20^{\text {th }}$ century by W.C. Mann and S.A. Thompson describes a text as a network in which text fragments are linked by semantic relations. The theory is considered to be a useful tool for text analysis. Besides, it offers an opportunity to determine the semantic structure of a text and investigates semantic relations, mostly specific to a certain type of text. Among its advantages it should be stated the following: 1) the list of relations doesn't depend on the size of fragment; 2) rhetorical relations join either Nucleus and Satellite (Elaboration, Antithesis etc.) or two or more Nuclei (Joint, Contrast etc.).
RTS describes two types of rhetorical relations according to different discourse levels:

- subject matter relations are used to reflect situation in the real world;

- presentational relations are known to characterize discourse events and have impact on readers [1].

Originally RST was created in order to create the models of argumentative discourses. In particular, it describes eighteen types of causal relations (Evidence, Justify, Volitional Cause, Volitional Result, Background, Solutionhood, Motivation, Non-Volitional Cause, Non-Volitional Result, Concession etc.) [2].

However, a superstructure can't be shown within the framework of TRS because the rhetorical graphs reflect semantic structure of only a certain fragment $[3$, p. 4]. Therefore, there is a need to explore opportunities of the theory concerning the features of a certain type of text. In particular, English scientific review paper is of interest in this context.

Analysis of recent researches and publications. Numerous models of scientific discours (ScholOnto, ABCDE, SWAN, SALT) are intended to facilitate computer processing of information. Thus, abstracts and introductions of scientific articles are generated automatically [4].

T.V. Yahontova investigated typical stylistic characteristics of scientific genres. In the monograph, special attention is given to the genre of scientific paper and its subgenres [5].

All the models mentioned consider argumentative strategies as integral to scientific discourse. On the other hand, science is a common sphere of argumentative application. It bears underlining that scientific discourse can be suggested as a special case of argumentative.

An important role in this context has been given to genre features of argumentation in scientific discourse. In particular, argumentative structure of technical research paper was described $[6 ; 7]$.

However, scientific review paper has unique features. The aims of the article are therefore the following: 1) to capture the patterns of argumentative structure in the genre of scientific review paper; 2) to describe semantic relations within them in terms of RST.

Research Methods. The study was performed using such methods as intention analysis, genre analysis, function analysis and analysis of rhetorical structures. The foundation of intention analysis is the author's desire to persuede the reader which is the criterion of argumentation. This information usually performs the function 
of Claim or Backing in the model of argument. The search process occurs according to two types of indicators. The first of them results from genre analysis which is based on typical compositional structure of the scientific review paper. The purpose and content of each chapter is established giving opportunity to reveal its role in argumentation and select some text fragments for further analysis.

The indicators of the second type show the presence of causation and help to identify Claims, e.g. therefore, consequently, thus, since, cause, result etc. However, the sentences found need additional analysis, since causation is necessary but insufficient condition for argumentation.

Identification of Grounds, Rebuttal, Modality and Warrant are performed with the help of function analysis. Looking at the term of function as a role within the system function analysis suggests that distinct units are considered in the context of their roles in the work of the whole system establishing certain functional interpretation. Besides, since functional and formal components don't coincide they are extracted and formed by the process of rearrangement [8].

Analysis of rhetorical structures is performed by dividing the text into discourse units and identifying rhetorical relations.

Presentation of main material. The constitutive requirements of scientific article as a genre are the following:

- it is a primary genre, i.e. the process of writing supposes direct communication;

- the length of article is considered to be middle (longer than abstract and shorter than monograph);

- the fact of publication that is proved by the presence of publication data;

- the purpose of writing is to represent the solution of one scientific task [9, p. 64-65].

To cover the features of a certain subgenre of scientific paper it is necessary to consider its existing classifications according to such criteria as: text presentation way, communicative and scientific tasks, type of research, sphere of scientific activity and scientific substyle $[10 ; 11]$.

The way of text presentation, review, is implied through the name of that subgenre. The communicative task of such an article is to think critically about the state of affairs in a particular brunch of science and technique. This characteristic determine the composition of this subgenre: abstract, introduction, review and analysis of the first object, review and analysis of the second object, ..., conclusions.

We look at argumentative discourse as a communicative speech formation consisting of a number of arguments. The structure of any argument is considered to contain six components: 1) the facts or other fully conclusive data called Grounds; 2) Claim or the statements whose truth the speaker wants the recipient to trust; 3 ) Warrant that that make it possible to move from Grounds to Claim; 4) Backing serving as foundation for Warrant; 5) Rebuttal establishing the action area of Warrant; 6) Modality describing the speaker's degree of certainty [12, p. 274-277].

Discourse of scientific papers is of argumentative type, since one of the purposes to write it is to persuade readers the conclusion made by the author is true. It supposes the presence of argumentation at the level of paper. The conclusion of the paper which serves as its Claim is based on a number of local Claims. Thus, argumentative structure of the whole article is framed in terms of hierarchical formation with argumen- tative fragments creating local argumentation. Besides, since abstract outlines the article briefly its argumentation is also reflected there. Therefore, there are three levels of argumentation of article in various degrees of detail.

Macrostructure of discourse is created by uniting fragments of discourse according to such macrorules as reduction of insignificant information, combination and generalization of uniform proposition [13, p. 29-50, 107-111].

Fragments constituted in this way are usually devoted to one topic. Despite the list of topics is known and limited macrostructure at the level of each chapter is unique. However, macrostructure of the whole article and its abstract have common features.

The argumentative structure of scientific review can be divided into two parts. The purpose of introduction chapter is to formulate the problem and justify the review of different ways to solve it. The rest of article is devoted to argumentation for the truth of conclusions.

To justify the fact of article feasibility the author of article must choose a certain strategy. It occurs with the help of establishing the order of topical units and logical relations between them expressed in rhetorical structures. The group of objects outlined in the articles of such a genre is devoted to a certain problem. Thus, the chapter of introduction mentions some its aspects.

The main reason to solve the problem is its importance. It is reflected with the help of Justify relation. (1) Defects in bearings may arise during use or during the manufacturing process. (2) Therefore, detection of these defects is important for condition monitoring as well as quality inspection of bearings [14, p. 469].

Connection between formulation of problems and general characteristics of devices solving it is expressed by such relations as Solutionhood.

(1) Said frequency range, however, is nowadays excessively crowded. (2) For this reason, a significant effort has been put in place for the development of wireless communication systems operating at mm-wave frequencies, where larger bandwidth is available so to satisfy future capacity needs. The main advantages of communication systems operating at mm-waves can be summarized as follows.... [15]. In other words, the problem is occupancy of frequency range. The way to solve it is necessary to develop wireless communication systems operating at another range.

The purpose of paper often results from the description of previous researches or current state of affairs in a certain area of science and technique.

(1) A lot of research work has been published, mostly in the last two decades, on the detection and diagnosis of bearing defects by vibration and acoustic methods.... (2) Therefore, the objective of the present study is to update these reviews by incorporating recent works and the advanced techniques adopted in bearing defect detection [14, p. 469].

The relation between (1) and (2) can be defined both as Background and Evidence.

The main part of article containing review and analysis of objects includes the generalized fragment of considerations and comments followed by the object descriptions.

(1) The different antenna concepts available in the scientific literature offer a variety of design choices for array antennas which, with different characteristics, can strongly affect the overall system performance. ... 
(2) Microstrip patch antennas are relatively easy to manufacture using technologies which are commonly available in industry ...

(3) Vivaldi antennas ... may represent a valid alternative to other antenna solutions in different applications. ....

(4) Dielectric resonator antennas (DRAs) display excellent characteristics for high-frequency applications and in particular for mm-wave communications and remote sensing ....

(5) ...open-ended waveguide antennas are largely employed in array configuration for mm-wave applications. ...

(6) Resonant cavity antennas (RCAs) can also be a class of antennas to be considered for mm-wave applications [15]. In the example there is a relation of Elaboration between the generalized unit (1) as a Nnucleus and units (2), (3), (4), (5), (6) served as Satellites.

The content of conclusions chapter results from the process of the reviewed objects comparison. Firstly, the author usually emphasizes some common features of objects: From a review of studies on vibration and acoustic measurement techniques for the detection of defects in rolling element bearings, it is seen that the emphasis is on vibration measurement methods [14, p. 477].

Then the focus is made on the difference between the objects: In order to provide the reader with a rational classification, two different use cases have been identified: PtM and PtP wireless communications. ... For the first use case scenario, patch antenna arrays ... For the second use case scenario, instead, reflect arrays ... [15]. In doing so, the author highlights advantages and disadvantages of some objects: Vibration measurement in the frequency domain has the advantage that it can detect the location of the defect. ... The method has a disadvantage that advanced damage is difficult to detect by this method [14, p. 477].

Besides, one of conclusions could be devoted to perspectives of further research: In the future, important opportunities will be offered by the advent of $6 G$ communication systems [15].

Thus, the argumentation occurs by means of representing a number of coordinate arguments where conclusions of article serve as Claims. The generalized conclusion is based on description of objects connected by rhetorical relation of Joint. Other conclusions are included in arguments based on text fragments linked with the help of such relations as Concession, Antithesis and Contrast.

Unlike technical research papers abstract of scientific review only briefly outline the content of paper and doesn't contain argumentation fragments.

Conclusions. Scientific review has all the hallmarks and features of scientific article as a genre. In particular, the stable composition is predetermined by its communicative and scientific tasks.

Argumentative structure of such an article consists of two parts: 1) justification for the authors to do this review in the chapter of introduction; 2) argumentation for the conclusions of article. The Claims of both constructions suggest some estimation of the researches reviewed.

Justification of review is based on the limited set of topics: importance of the study subject, history of research, disadvantagies of previous methods. Argumentation for the conclusions are coordinate with fragments of object descriptions serving as Grounds.

The further research will be connected with analysis of other types scientific papers and other genres of scientific discourse.

\section{References:}

1. Mann W.C., Thompson S.A. Rhetorical structure theory: toward a functional theory of text organization. Interdisciplinary Journal for the Study of Discourse, 1988. Vol. 8, Issue 3. P. 243-281.

2. Сусов А.А. Каузальные риторические отношения. Тверской лингвистический меридиан. Тверь, 2006. Вып. 6. С. 55-81. URL: http:/homepages.tversu.ru/ ips/ASusov2006d.html (дата звернення: 8.10.2021).

3. Mann W.C., Massthiessen C.M. I. M., Thompson S.A. Rhetorical structure theory and text analysis. Los Angeles : Information Sicience Institute, $1989.60 \mathrm{p}$.

4. Groza T.A., Handschuh S., Clark T., Buckingham S. A short survey of discourse representation. Proceedings 8th International Semantic Web Conference, Workshop on Semantic Web Applications in Scientific Discourse. Lecture Notes in Computer Science, Springer Verlag (Berlin, 26 October, 2009), Washington DC, 2009. URL: http:// oro.open.ac.uk/18565/ (Last accessed: October 8, 2021).

5. Яхонтова Т.В. Лінгвістична генологія наукової комунікації : монографія. Львів : Видавничий центр ЛНУ ім. Івана Франка, 2009. $420 \mathrm{c}$.

6. Доронкіна Н.С. Жанрові особливості аргументаціїу науковому дискурсі. Наукові записки. Серія: Філологічні науки (мовознавство). Кропивницький : Вид. Лисенко В.Ф., 2017. Вип. 153. С. 365-369.

7. Doronkina N.Ye. Argumentative discourse of technical research papers in the context of rhetorical structure theory. Вісник Наиіонального технічного університету Украӥни «Київський політехнічний інститут». Серія: Філологія, педагогіка. Київ : НТУУ, 2016, Вип. 7. С. 21-25.

8. Демьянков В.З. Функционализм в зарубежной лингвистике конца XX века языка. Когнитивные аспекты лексикографии. 2003. URL: http://www.infolex.ru/Func.htm\#0 (дата звернення: 8.10.2021).

9. Михайлова Е.В. Жанры научного дискурса. Языковая личность: жанровая речевая деятельность. Волгоград : Перемена, 1998. C. 64-65.

10. Богданова В.А. Научный стиль. Функциональные стили и формы речи. Саратов, 1993. С. $35-65$.

11. Карачун Ю.Г. Структурно-семантичний та функційно-прагматичний аспекти термінів-іменників в англійськомовних текстах 3 електричної інженерії : дис. ... канд. філол. наук : 10.02.04. Київ, 2019. $396 \mathrm{c}$

12. Филиппов К.А. Лингвистика текста: курс лекцій. Санкт-Петербург : Изд-во С.-Петербург. ун-та, 2007. - 331 с.

13. Dijk T.A. van. Macrostructures. New Jersey : Erlbaum, 1980. 317 p.

14. Tandon N., Choudhury A. A review of vibration and acoustic measurement methods for the detection of defects in rolling element bearings. Tribology International, 1999. 32 (8), P. 469-480. URL: https://doi.org/10.1016/S0301-679X(99)00077-8 (Last accessed: October 8, 2021).

15. G. Federico, D. Caratelli, G. Theis, A.B. Smolders. "A Review of Antenna Array Technologies for Point-to-Point and Pointto-Multipoint Wireless Communications at Millimeter-Wave Frequencies". International Journal of Antennas and Propagation, 2021. Vol. 2021. URL: https://doi.org/10.1155/2021/5559765 (Last accessed: October 8, 2021).

Івасюк О., Доронкіна Н. Особливості аргументації наукової оглядової статті у контексті теорії риторичних структур

Анотація. Дослідження присвячене спробі використання теорії риторичних структур задля опису аргументативної структури наукової оглядової статті. Метою розвідки є як висвітлення характерних рис, притаманних науковій оглядовій статтіякпіджанру наукової статті, так і окреслення семантичних відношень між 
компонентами аргументативної структури. У дослідженні використано методи жанрового аналізу, інтенційного аналізу, функційного аналізу та аналізу риторичних структур. Розглянуто такі характеристики наукової статті, як композиція, комунікативне та наукове завдання, а також конститутивні ознаки. Також обговорено такі критерії виділення піджанру, як: спосіб презентації тексту, комунікативне та наукове завдання, тип дослідження, сфера наукової діяльності та підстиль наукового стилю. Дослідження наукової оглядової статті було проведене на основі панаргументативного підходу, який передбачає наявність аргументативних фрагментів у досліджуваному тексті. Структура кожного аргументативного фрагменту базується на моделі, яку запропонував С. Тулмін. Оскільки аргументативна структура жанру наукової статті предстає у формі ієрархічної побудови, проаналізовано особливості наукової оглядової статті, що притаманні кожному рівню iєрархії. 3'ясовано, що аргументативна структура наукової оглядової статті складається 3 двох частин. Перша 3 них слугує основою вступного розділу, зміст якого становить визначення проблеми та переконання читача в тому, що проведення огляду шляхів іiі вирішення доцільне. Друга частина аргументативної структури належить до сурядного типу складної аргументації на користь висновків статті, які знаходяться у відповідному розділі. Визначено типові для наукової оглядової статті риторичні відношення, що задіяні в аргументативних структурах. Дослідження проілюстроване текстовими фрагментами двох оглядових статей у галузі акустики та радіоелектроніки.

Ключові слова: сурядна аргументація, риторичне відношення, піджанр, дискурс, ієрархічна побудова, анотація, обгрунтування. 